\title{
FEATURE Understanding and managing the causes of soil variability
}

\author{
David A. Lobb
}

0 ver the past few decades, a tremendous amount of time and money has gone into developing and applying technologies to manage crop variability within fields. Table 1 lists in order the factors that most commonly cause crop variability. The information in this table was developed by Aspinall (1997) based on several years of experience in southern Ontario, and it is considered to apply to many other agricultural regions. Clearly, there are many causes of crop variability, and several are either directly or indirectly linked to soil erosion.

The purpose of this paper is to bring attention to soil erosion as a cause of soil landscape variability and to the potential to affect crop variability by managing soil erosion. The underlying message is that sound management of variable soil landscapes requires a balanced approach - the causes of the variability must be managed as well as the effects.

\section{THE IMPACT OF CULTIVATION AND SOIL EROSION ON SOIL LANDSCAPE VARIABILITY}

Figure 1a shows the soils within a natural, uncultivated, hilly landscape, typical of the Canadian prairies around 1900 when the land was broke for agriculture. Figure 1 is a reproduction of an illustration by Ellis (1938) of the impact of cultivation and soil erosion on the soils of a hilly prairie landscape. Soils are thinner on hilltops and thicker at the base of hillslopes. This pattern is most intense in hummocky landscapes where the slopes diverge from knolls and converge towards depressions, a characteristic feature of the Prairie Pothole Region of the North American Great Plains. The variation in soil thickness reflects the topography of the landscape and its influence on hydrology, biologic activity, and soil forming processes. Soil erosion is pre-

David A. Lobb is professor of Landscape Ecology and Senior Chair of Watershed Systems Research at Landscape Dynamics Laboratories, Department of Soil Science, University of Manitoba, Winnipeg, Manitoba, Canada.

\begin{tabular}{|c|c|}
\hline Cause & Description \\
\hline Soil moisture & $\begin{array}{l}\text { Excesses in lower slope landscape positions (depressions) and } \\
\text { deficits in upper slope positions (knolls) }\end{array}$ \\
\hline Variety & Crop sensitivity to adverse and advantageous conditions \\
\hline Pests & Insect, weed, and disease problems \\
\hline Crop rotation & Crop selection \\
\hline Tillage & Timing and systems (associated with weeds and seedbed suitability) \\
\hline Soil compaction & $\begin{array}{l}\text { Induced by tillage and traffic (particularly on headlands) and ex } \\
\text { posed by soil erosion (particularly on knolls) }\end{array}$ \\
\hline Soil pH & $\begin{array}{l}\text { Acidity problems associated with poor drainage (particularly in } \\
\text { depressions) and alkalinity problems associated with exposed } \\
\text { calcareous subsoil (particularly on eroded knolls) }\end{array}$ \\
\hline Herbicide management & Drift, selection, timing, and rates (includes misses and overlaps) \\
\hline Subsoil conditions & Depth to subsoil, compactness, and permeability \\
\hline Fertilizer management & Placement and rates (includes misses and overlaps) \\
\hline Soil fertility & Levels and balance of nutrients \\
\hline Plant population & Inconsistencies in seeding and emergence \\
\hline
\end{tabular}

sumed to be negligible due to the presence of a permanent vegetative cover.

Cultivation can dramatically affect the variability of soils within landscapes, as shown in figure $1 \mathrm{~b}$. Figure $1 \mathrm{~b}$ shows the impact of tillage between about 1900 and 1935. The hilltop has been stripped of topsoil, and soil has accumulated at the base of the slope. It can be presumed that the severity and extent of soil erosion within such landscapes would be much greater with several decades more of tillage, particularly if that tillage is more intense (figure 1c).

Obviously, soil erosion must have a major impact on the variability of our soil landscapes and, therefore, the variability of our crops. The soil erosion observed in figure $1 \mathrm{~b}$ will result in greater movement of water from hilltops, amplifying soil moisture variability. The soil erosion will also expose subsoil that has a lower production potential for crops. It is extremely important to recognize that if soil erosion is a cause of soil landscape variability, this variability is not static-it will increase in severity and extent under continued cultivation. Figure 1d illustrates the consequence of continued cultivationunproductive subsoil that is exposed on the eroded hilltops is dragged down the hillslope and buries productive topsoil at the base of the hillslope. Many examples of such "inverted" soil profiles already exist in the prairies. Over time, the whole soil landscape becomes less productive but more uniform.

\section{TILLAGE EROSION AS THE DOMINANT EROSION PROCESS}

If farmers are to control soil erosion in an effort to manage soil landscape variability, they must know which of the erosion processes to control. The pattern of soil redistribution observed by Ellis in the 1930s and widely observed since is inconsistent with either wind erosion or water erosion. Soil losses in landscapes dominated by water erosion are most severe on lower backslopes, not hilltops. Although soil losses in landscapes dominated by wind erosion are most severe on exposed rises in the landscape, the universality of the observed pattern and rates rules out wind erosion. The observed soil losses are equally severe on fine sands and gravelly clay loams and are equally severe on sheltered and unsheltered hilltops. Where directionality is evident, it does not match the prevailing wind directions - it matches 


\section{Figure 1}

Soil-landscape variability in a typical hummocky landscape in the prairies: (a) natural grassland, prior to cultivation (circa 1900); (b) after a few decades of cultivation (circa 1935), a juvenile state of degradation by soil erosion; (c) after several decades of cultivation (circa 1990), a mature state of degradation; (d) an advanced state of degradation; and (e) the rehabilitation of severely eroded land and moving soil from areas of soil accumulation to areas of loss. (Figures $1 \mathrm{a}$ and $\mathrm{b}$ are adapted from an illustration of a typical Manitoba soil landscape by Ellis [1938]).

(a)

(b)

(c)

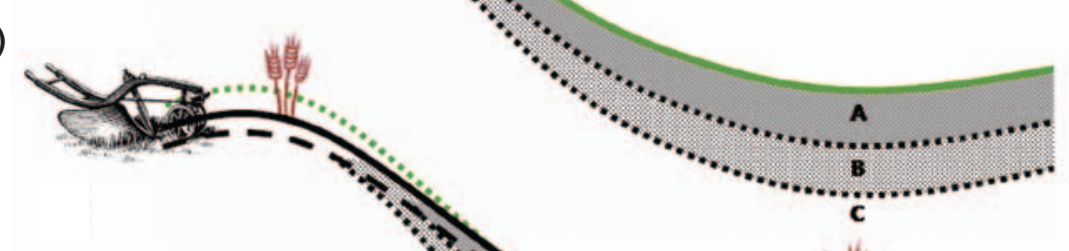

(d)

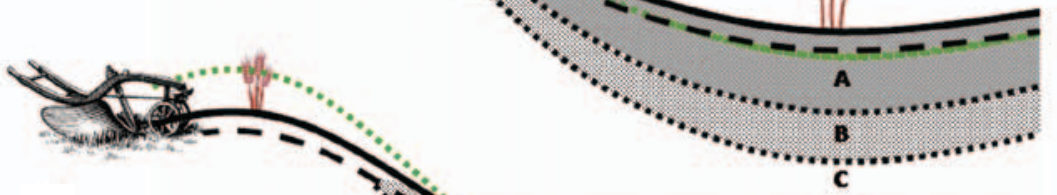

(e)
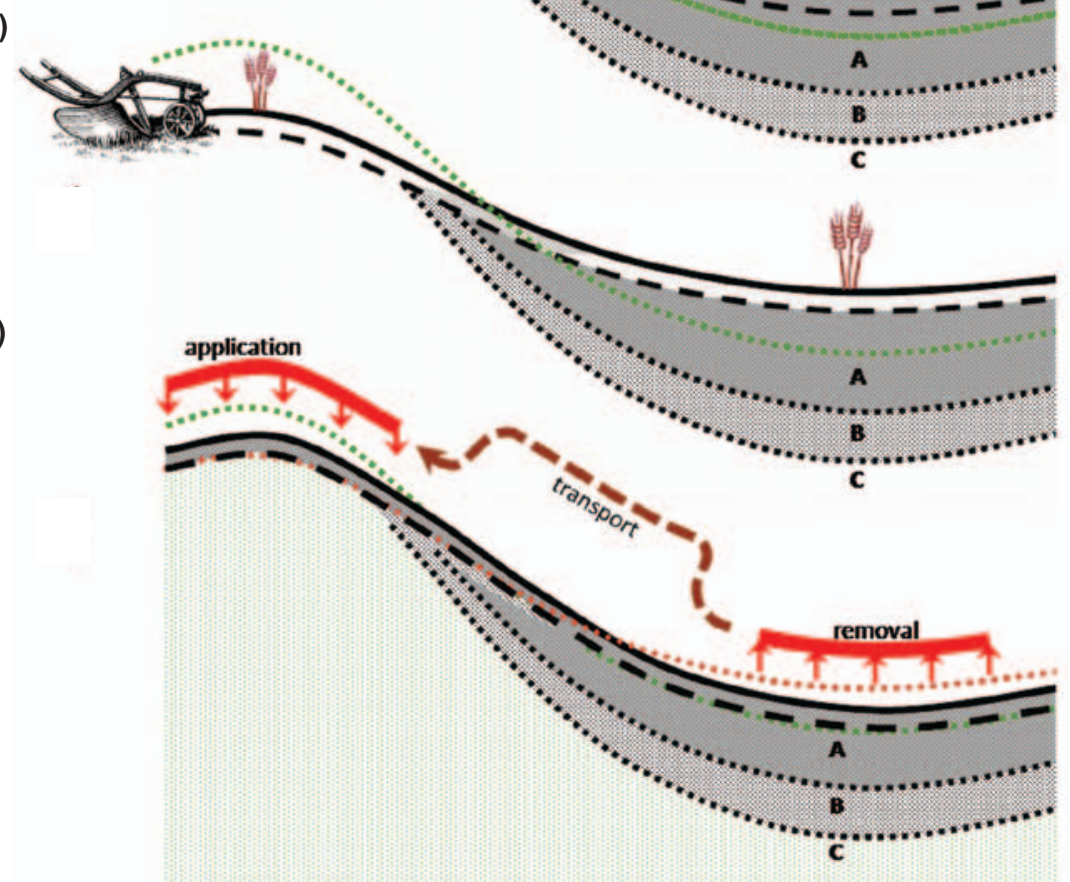

tillage patterns. The observed pattern and severity of soil redistribution is consistent with tillage erosion. Compared to wind and water erosion, tillage erosion has only
Research conducted in Canada (Lobb et al. 1995, 1999; Li et al. 2007a, 2007b, 2008; Tiessen et al. 2007a, 2007b, 2008) and elsewhere in the world (Lindstrom et al. 1990; Govers et al. 1999; Tiessen et al. 2010) has demonstrated that tillage moves a tremendous amount of soil within cultivated landscapes. The amount of soil moved by tillage within the majority of these landscapes is highly variable. The effects of this variability are most apparent in hilly landscapes. Typically, more soil is moved while tilling in the downslope direction than while tilling in the upslope direction, the amount of soil moved being a function of slope gradient. Tillage erosion-the progressive net downslope movement of soil-is responsible for severe soil loss on upper slope landscape positions and soil accumulation in lower slopes.

The loss of topsoil and exposure of subsoil on upper slopes normally amplifies the variability in soil properties, affecting crop production and other biophysical processes. The research that has been conducted suggests that tillage erosion is the major cause of soil loss on the hilltops of cultivated landscapes. Visual evidence of tillage erosion is widespread and includes (a) loss of organic rich topsoil and exposure of subsoil at the summit of ridges and knolls (figures 2 and 3) and (b) undercutting of field boundaries, such as fence lines and terraces, on the downslope side and burial on the upslope side. Tillage erosion not only redistributes soil within a landscape, it also leaves the soil more susceptible to wind and water erosion by exposing subsoil which is more erodible and by delivering topsoil to areas of the landscape where water erosion is more severe.

\section{MANAGING SOIL LANDSCAPE VARIABILITY BY REDUCING TILLAGE}

Conservation tillage leaves more crop residue on the soil surface, thereby reducing the soil's exposure to wind and water erosion. Most conservation tillage practices also reduce the movement of soil, which normally reduces tillage erosion. By reducing soil erosion, conservation tillage will decrease severity and extent of 


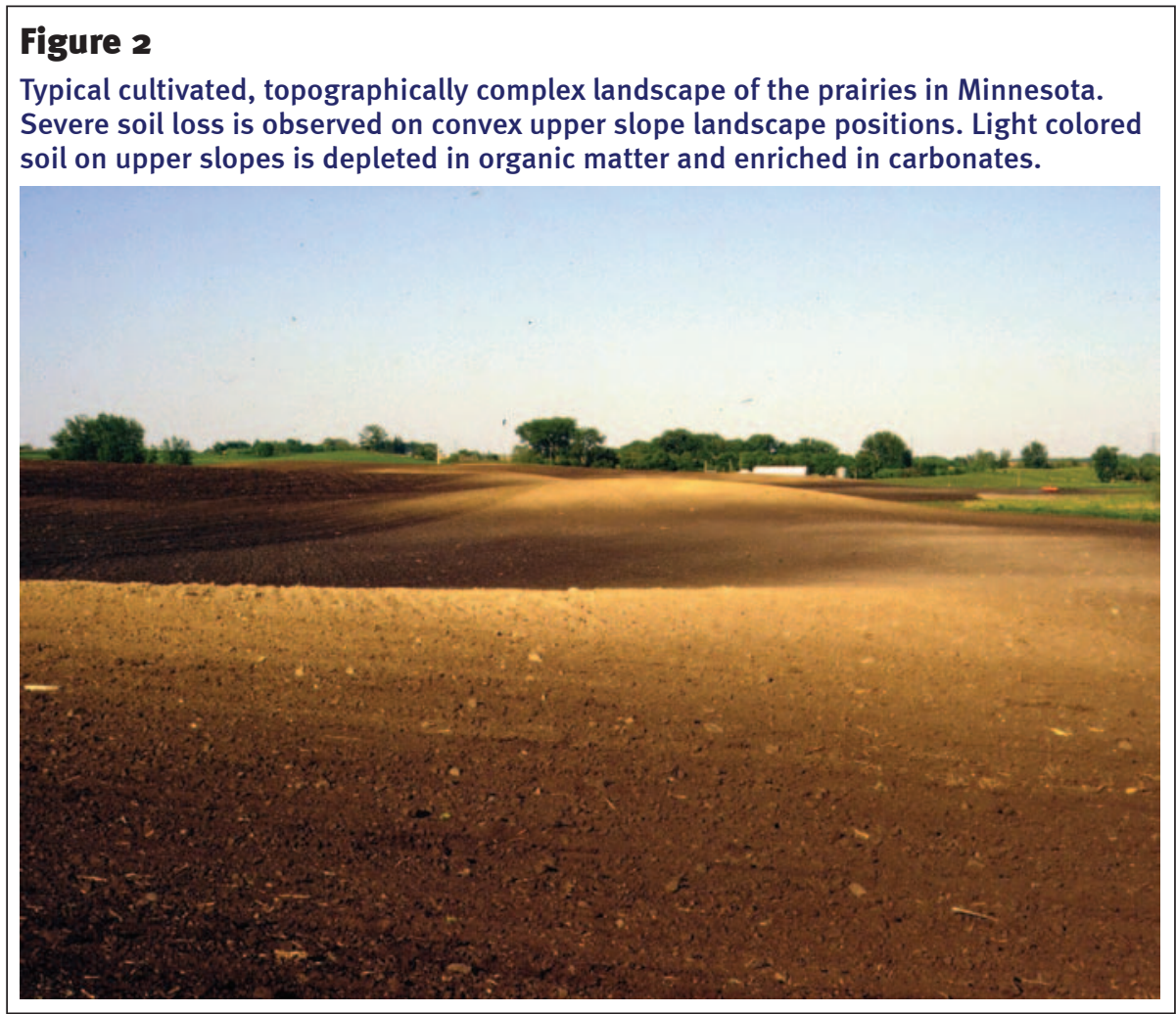

\section{Figure 3}

A prairie landscape that is severely eroded by soil erosion in Minnesota. In the foreground, note the calcareous subsoil tilled to the surface where it will be incorporated into the till layer.

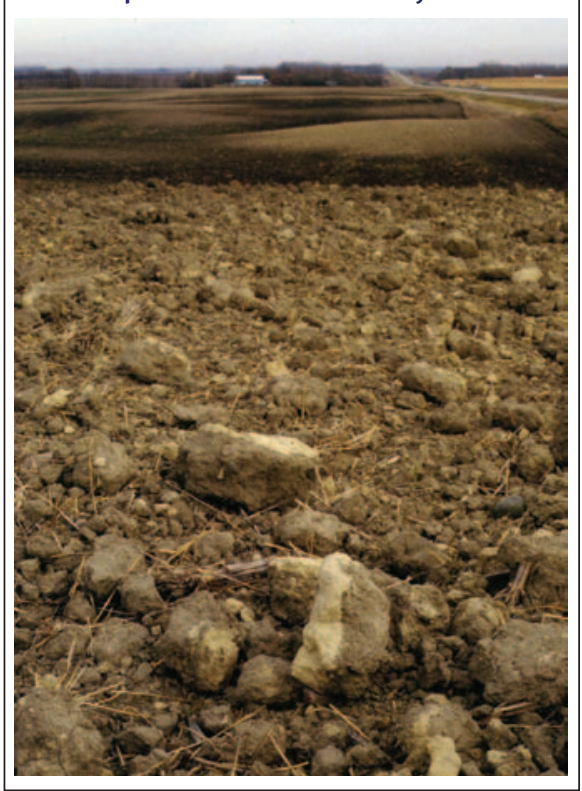

soil loss, and, therefore, it will decrease soil landscape variability.

One of most commonly used practices in converting from conventional tillage to conservation tillage is the use of a chisel plow rather than a moldboard plow. The chisel plow leaves far more crop residue on the soil surface. Although the chisel plow reduces the risk of wind and water erosion, it may not reduce tillage erosion-it may increase it (table 2). This is because the chisel plow can move as much soil as the moldboard plow, and it can move it to a greater distance. Another conservation practice is the reduction in the number of passes of discs and cultivators used in secondary tillage operations. However, in some forms of crop production, such as potato production, there is little crop residue to work with, and tertiary tillage operations such as seeding, hilling, and harvesting may result in more tillage erosion than primary and secondary tillage operations combined (table 3). The most extreme form of conservation tillage is the use of no-till or zero-till systems. In these systems, both primary and secondary tillage operations are eliminated, and the crop is seeded directly into the untilled soil (into the residue of the preceding crop).

\section{Table 2}

Tillage translocation and tillage erosivity of operations used to prepare seedbeds.

\begin{tabular}{|c|c|c|c|c|c|}
\hline \multirow[t]{2}{*}{ Tillage implement } & \multirow[t]{2}{*}{ Tillage practice } & \multicolumn{3}{|c|}{$\begin{array}{l}\text { Tillage translocation: } \\
\text { Soil movement on level land }\end{array}$} & \multirow[t]{2}{*}{$\boldsymbol{\beta}^{*}$} \\
\hline & & $\mathrm{T}_{\mathrm{L}}^{*}(\mathrm{~m})$ & $\lambda_{90} *(\mathrm{~m})$ & $\mathrm{T}_{\mathrm{M}} *\left(\mathrm{~kg} \mathrm{~m}^{-1}\right)$ & \\
\hline Moldboard plow $\dagger$ & Primary tillage & 0.22 & na & 76 & 1.0 \\
\hline Chisel plow $†$ & Primary tillage & 0.21 & na & 55 & 1.0 \\
\hline Tandem disc† & Secondary tillage§ & 0.27 & 0.48 & 50 & 2.0 \\
\hline Cultivator† & Secondary tillage§ & 0.31 & na & 57 & 0.1 \\
\hline Moldboard plow $\ddagger$ & Primary tillage & 0.18 & 0.49 & 43 & 1.8 \\
\hline Chisel plow $\ddagger$ & Primary tillage & 0.29 & 2.05 & 64 & 1.9 \\
\hline Offset disc $\neq$ & Secondary tillage§ & 0.24 & 0.90 & 34 & 1.8 \\
\hline Cultivator $\ddagger$ & Secondary tillage§ & 0.19 & 1.41 & 35 & 0.3 \\
\hline
\end{tabular}

$* T_{L}=$ average distance of soil movement in till layer. $\lambda_{90}=90$ th percentile of distance to which translocated soil is moved, and $10 \%$ of soil translocated exceeds this distance. $\mathrm{T}_{\mathrm{M}}=$ mass of soil moved per meter width of tillage. $\beta=$ tillage erosivity, the mass of soil moved per meter width of tillage per percent of slope grade (gradient being positive for tillage in the downslope direction).

† Experiments carried out in Ontario, Canada, in 1990 (Lobb et al. 1999).

‡ Experiments carried out in New Brunswick, Canada, in 2005 (Tiessen et al. 2007a).

$\S$ Disc following moldboard plow, and cultivator following disc following moldboard plow.

This eliminates tillage erosion from tillage operations and reduces the susceptibility of the soil to wind and water erosion by leaving crop residue on the soil surface and maintaining soil structure. Although no-till and zero-till systems eliminate tillage erosion from primary and secondary tillage operations, they can still result in significant soil movement and tillage erosion during seeding. High disturbance seeders can cause as much tillage erosion as the mouldboard plough (table 4).

If a farmer wants to arrest increases in soil landscape variability associated with 


\section{Table 3}

Tillage translocation and tillage erosivity of cropping operations.

\begin{tabular}{|c|c|c|c|c|c|}
\hline \multirow[t]{2}{*}{ Tillage implement } & \multirow[t]{2}{*}{ Tillage system } & \multicolumn{3}{|c|}{$\begin{array}{l}\text { Tillage translocation: } \\
\text { Soil movement on level land }\end{array}$} & \multirow[t]{2}{*}{$\beta^{*}$} \\
\hline & & $\mathrm{T}_{\mathrm{L}}{ }^{*}(\mathrm{~m})$ & $\lambda_{90} *(\mathrm{~m})$ & $T_{M} *\left(k g ~ m^{-1}\right)$ & \\
\hline $\begin{array}{c}\text { Potato planter plus two } \\
\text { passes of hiller†‡ }\end{array}$ & Conventional tillage & 0.42 & 3.72 & 117 & 3.6 \\
\hline Potato harvester $\ddagger$ & Conventional tillage & 0.55 & 0.91 & 70 & 3.0 \\
\hline
\end{tabular}

$* T_{L}=$ average distance of soil movement in till layer. $\lambda_{90}=90$ th percentile of distance to which translocated soil is moved, and $10 \%$ of soil translocated exceeds this distance. $T_{M}=$ mass of soil moved per meter width of tillage. $\beta=$ tillage erosivity, the mass of soil moved per meter width of tillage per percent of slope grade (gradient being positive for tillage in the downslope direction). † The planting operation with discs followed by two passes of hilling tools.

‡ Experiments carried out in New Brunswick, Canada, in 2005 (Tiessen et al. 2008).

\section{Table 4}

Tillage translocation and tillage erosivity of seeding operations.

\begin{tabular}{|c|c|c|c|c|c|}
\hline \multirow[t]{2}{*}{ Tillage implement } & \multirow[t]{2}{*}{ Tillage system } & \multicolumn{3}{|c|}{$\begin{array}{l}\text { Tillage translocation: } \\
\text { Soil movement on level land }\end{array}$} & \multirow[t]{2}{*}{$\beta^{*}$} \\
\hline & & $\mathrm{T}_{\mathrm{L}}{ }^{*}(\mathrm{~m})$ & $\lambda_{90} *(\mathrm{~m})$ & $\mathrm{T}_{\mathrm{M}} *\left(\mathrm{~kg} \mathrm{~m}^{-1}\right)$ & \\
\hline Air-seeder with knives $†$ & Conventional tillage & 0.12 & 0.69 & 4.4 & 0.14 \\
\hline $\begin{array}{l}\text { Cultivator plus air-seeder } \\
\text { with knives } \dagger\end{array}$ & Conventional tillage & 0.34 & 1.1 & 35 & 1.0 \\
\hline Air-seeder with knives $\ddagger$ & Zero-till & 0.16 & 0.88 & 8.2 & 0.1 \\
\hline Air-seeder with sweeps $\ddagger$ & Zero-till & 0.51 & 1.3 & 30 & 1.0 \\
\hline
\end{tabular}

$* T_{L}=$ average distance of soil movement in till layer. $\lambda_{90}=90$ th percentile of distance to which translocated soil is moved, and $10 \%$ of soil translocated exceeds this distance. $\mathrm{T}_{\mathrm{M}}=$ mass of soil moved per meter width of tillage. $\beta=$ tillage erosivity, the mass of soil moved per meter width of tillage per percent of slope grade (gradient being positive for tillage in the downslope direction). † Experiments carried out in Manitoba, Canada, in 2004 (Li et al. 2007a).

‡ Experiments carried out in Saskatchewan, Canada, in 2006 (Lobb 2008).

soil erosion, the obvious solution is to eliminate tillage from their crop production system. The elimination of tillage will eventually reduce soil landscape variability, but it may take decades- the areas of greatest need receive and store the least moisture and produce the least biomass within the landscapes.

Over the last few decades, there has been widespread adoption of conservation tillage across Canada and in many other parts of the world. The adoption of no-till or zero-till exceeds $50 \%$ of cropped land in the Canadian prairies (Huffman and Eilers 2010). However, in this region, about $25 \%$ of cropped land continues to be managed using conventional tillage (primary and secondary tillage operations). It is probable that tillage will remain an integral component of many cropping systems, such as are less productive than the original soil. In contrast, where tillage erosion is the major erosion process, the eroded soil is locally available in concave lower slopes and remains highly productive, creating an opportunity for restoration.

Between 2004 and 2006, a large-scale field study was conducted in the undulating and hummocky landscapes of southwestern Manitoba to examine the impact of soil landscape restoration on crop productivity (Smith 2008). Four study sites (one primary and three secondary sites) were selected to compare crop productivity on severely eroded upper slope positions that had been restored with the addition of $10 \mathrm{~cm}$ (3.94 in) of topsoil with crop productivity on those that had not been restored. Comparisons were also made between crop yields in lower slope positions where topsoil was removed with those areas where it was not. Crop emergence in addition plots occurred at a faster and more consistent rate than in control plots. Overall, there was a $60 \%$ greater plant population in addition plots. At the primary site, crop yields in addition plots increased by $31 \%$ in the first year after restoration and continued to increase the following year reaching $64 \%$ increase. Yield increases also occurred at each secondary site and ranged from 10\% to $133 \%$ in comparison with control plots. The effect of added topsoil on eroded hilltops was more evident during a year with below-normal precipitation. At two of the three sites where lower slope positions were monitored, there were no significant reductions in crop yield where topsoil had been removed. When crop yields were normalized across all research sites, relative to regional crop yield averages, yield differences between upper slope treatment plots were significantly greater than yield differences between lower slope treatment plots. Therefore, adding $10 \mathrm{~cm}$ of topsoil to severely eroded hilltops resulted in a net benefit in crop productivity within the landscape.

A complementary economic assessment of the practice of landscape restoration was carried out with mathematic simulations (Johnson et al. 2009). Model simulations were carried out using farm survey information collected in the summer of 2007. 
Since the need for landscape restoration is primarily the result of soil erosion, three tillage scenarios were used in the simulations: conventional tillage with high rates of soil loss, conservation tillage with moderate rates of soil loss, and no-till or zero-till with very low rates of soil loss. In addition, two restoration scenarios were also considered: with and without restoration. The without restoration scenario was included to assess the benefit of the restoration practice over the status quo which results in continued soil erosion, loss of soil productivity, and declining crop yields. The economic assessment was based on the payback period, which included initial and subsequent restoration costs. Subsequent restoration may be required under cropping and tillage systems that result in substantial soil loss from hilltops, i.e., conventional tillage. The payback period was found to be between 3.8 to 5.7 years under a variety of scenarios. The payback period depends upon several factors, of which the crop rotation is the strongest determining factor.

Research on the practice of landscape restoration also includes examinations of soil properties (Smith 2008; Papiernik et al. 2009), weeds, and greenhouse gasses (Erb 2005) and continues with study sites in Minnesota, South Dakota, and Manitoba. The findings of these studies demonstrate that soil landscape restoration is a feasible land management practice for restoring crop productivity on severely eroded hilly land. This practice may be the most effective means of managing soil landscape variability and a key component of an effective precision conservation strategy.

\section{REFERENCES}

Aspinall, J.D. 1997. The Ontario site specific cropping management project. In Precision farming: Challenges and opportunities for Atlantic Canada, ed. D.A. Lobb, 5-8. Grand Falls, New Brunswick, Canada: Eastern Canada Soil and Water Conservation Centre.

Ellis, J.H. 1938. The Soils of Manitoba. Winnipeg, Manitoba: Manitoba Economic Survey Board.

Erb, M.M. 2005.The Effects of Landscape Restoration on Greenhouse Gas Emissions and Plant Species and Abundance. Master's thesis. Department of Soil Science, University of Manitoba. Winnipeg, Manitoba, Canada.
Govers, G., D.A. Lobb, and T.A. Quine. 1999. Tillage erosion and translocation: emergence of a new paradigm in soil erosion research. Soil Tillage Research 51:167-174.

Huffman, E.C., and W. Eilers. 2010. Agricultural land use. In Environmental Sustainability of Canadian Agriculture: Agri-Environmental Indicator Report Series-Report \#3, eds. W. Eilers, R. McKay, L. Graham, A. Lefebvre, 14-19. Ottawa, Ontario, Canada: Agriculture and Agri-Food Canada.

Johnson, G.V., A. Hacault, and D.A. Lobb. 2009 Landscape restoration: Restoration of productivity on severely eroded land-economic assessment. Agriculture Research and Development Initiative, ARDI 04-639. Morris, Manitoba, Canada.

Li, S., D.A. Lobb, and M.J. Lindstrom. 2007a. Tillage translocation and tillage erosion in cereal-based production in Manitoba, Canada. Soil Tillage Research 94:164-182.

Li, S., D.A. Lobb, M.J. Lindstrom, and A. Farenhorst. 2007b. Tillage and water erosion on different landscapes in the northern North American Great Plains evaluated using the ${ }^{137} \mathrm{Cs}$ technique and soil erosion models. Catena 70:493-505.

Li, S., D.A. Lobb, M.J. Lindstrom, S.K. Papiernik, A. Farenhorst. 2008. Modelling tillage-induced redistribution of soil mass and its constituents within different landscapes. Soil Science Society of America Journal 72:167-179.

Lindstrom, M.J., W.W. Nelson, T.E. Schumacher, and G. Lemme. 1990. Soil movement by tillage as affected by slope. Soil Tillage Research 17:252-264.

Lobb, D.A. 2008. Soil movement by tillage and other agricultural practices. In Ecological Engineering, vol. 4 of Encyclopedia of Ecology, 1st ed (5 vols.), eds. S.E. Jorgensen and B.D. Fath, 3925-3303. Elsevier B.V., Oxford.

Lobb, D.A., R.G. Kachanoski, and M.H. Miller. 1995 Tillage translocation and tillage erosion on shoulder slope landscape positions measured using ${ }^{137} \mathrm{Cs}$ as a tracer. Canadian Journal of Soil Science 75:211-218.

Lobb, D.A., R.G. Kachanoski, and M.H. Miller. 1999. Tillage translocation and tillage erosion in the complex upland landscapes of southwestern Ontario. Soil Tillage Research 51:189-209.

Papiernik, S.K., T.E. Schumacher, D.A. Lobb, M.J. Lindstrom, M.L. Lieser, A. Eynard, and J.A Schumacher. 2009. Soil properties and productivity as affected by topsoil movement within an eroded landform. Soil Tillage Research 102 $67-77$.
Smith, D.M. 2008. The impact of landscape restoration on crop productivity and soil properties in severely eroded hilly landscapes in southwestern Manitoba. Master's thesis. Department of Soil Science, University of Manitoba. Winnipeg, Manitoba, Canada.

Tiessen, K.H.D., D.A. Lobb, G.R. Mehuys, and H.W. Rees. 2007a. Tillage erosion within potato production systems in Atlantic Canada: II. Erosivity of primary and secondary tillage operations. Soil Tillage Research 95:320-331.

Tiessen, K.H.D., G.R. Mehuys, D.A. Lobb, and H.W. Rees. 2007b. Tillage erosion within potato production systems in Atlantic Canada: I. Measurement of tillage translocation by implements used in seedbed preparation. Soil Tillage Research 95:308-319.

Tiessen, K.H.D., D.A. Lobb, G.R. Mehuys, and H.W. Rees. 2008. Measuring tillage translocation and tillage erosivity by planting, hilling and harvesting operations common to intensive potato production in Atlantic Canada. Soil Tillage Research 97:123-139

Tiessen, K.H.D., F.M. Sancho, D.A. Lobb, and G.R Mehuys. 2010. Assessment of tillage translocation and erosion by the disc plow on steepland Andisols in Costa Rica. Journal of Soil and Water Conservation 65(5):316-328. 